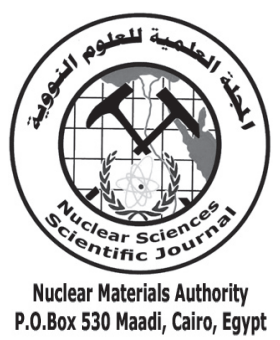

ISSN 2314-5609

Nuclear Sciences Scientific Journal

vol. 2, p 39 - 54

2013

\title{
GEOLOGY, PETROLOGY AND URANIUM DISTRIBUTION IN GRANITIC MASSES OF WADIS FALIQ EL-SAHL AND FALIQ EL-WAAR, NORTH EASTERN DESERT, EGYPT
}

\author{
REMON R. AYOUB \\ Nuclear Materials Authority, Cairo, Egypt
}

\begin{abstract}
Faliq El-Sahl and Faliq El-Waar granitic plutons are located in the north Eastern Desert. The field studies clarified that the younger granites are related to successive magmatic intrusions forming two main granitic masses and pegmatite within both granites. Petrographically, the main rock types of each of the two masses are monzogranites and syenogranites. Pegmatites could be classified into mineralized pegmatites within the syenogranites and non-mineralized pegmatites which are distributed within the monzogranites. The main fault trends cutting through the study area in decreasing order of predominance are NNWSSE, NW-SE, NE-SW and NNE-SSW. The younger granites are dissected by four major sets of joints, in decreasing order of abundance striking NW-SE, NE-SW, NNW-SSE and ENE-WSW.

Geochemically, the studied granites originate from peraluminous subalkaline magma considered as post orogenic within plate granites, intruded in a crust of thickness between $22 \mathrm{~km}$ and $30 \mathrm{~km}$; with Rb/Sr ratios range from 0.1 to 1.0 during crystallization of monzogranites but $\mathrm{Rb} / \mathrm{Sr}$ ratios range from 1.0 to 10.0 during crystallization of syenogranites. The geochemical ratios of the studied younger granites show similarity to a great extent suggesting that these granites represent outcrops of one batholith and originate by magmatic differentiation of the same magma.

The syenogranites could be considered as uraniferous granites (U 19-14 ppm, Th 31-26 ppm) originated from highly fractionated U-rich magma. In monzogranites uranium exist only in zircon, sphene and apatite. Uranium essentially concentrated during the magmatic stage in apatite and zircon. Both meteoric water and hydrothermal solutions allowed to liberate $\mathrm{U}+6$ and to be redepositing along microfractures supported by increasing uranium content in the secondary hematite and fluorite.
\end{abstract}

Pegmatites show higher U-contents relative to both granite types with presence of uranophane mineral within the syenogranites

\section{INTRODUCTION}

The area of study occupies ab. $310 \mathrm{~km}^{2}$ in the northern tectonic domain of the Eastern Desert (lat. $27^{\circ} 00^{\prime}$ and $27^{\circ} 10^{\prime} \mathrm{N}$ and long. $33^{\circ}$ $30^{\prime}$ and $\left.33^{\circ} 37^{\prime} \mathrm{E}\right)$, (Fig.1). It occupied by Pan African neoproterozoic crystalline basement rocks particularly the younger granites. The major wadis traversing the area have generally NE-SW and NNE-SSW trends. All wadis drain eastward to the Red Sea.
The main goal of this paper is focused on the petrography and geochemistry of the younger granites to clarify the radioactivity and geochemical behavior and distribution of uranium in these granitic plutons.

\section{GEOLOGIC SETTING}

The main rock types exposed in Wadi Faliq El-Sahl and W. Faliq El-Waar area can be chronologically arranged from old to young 


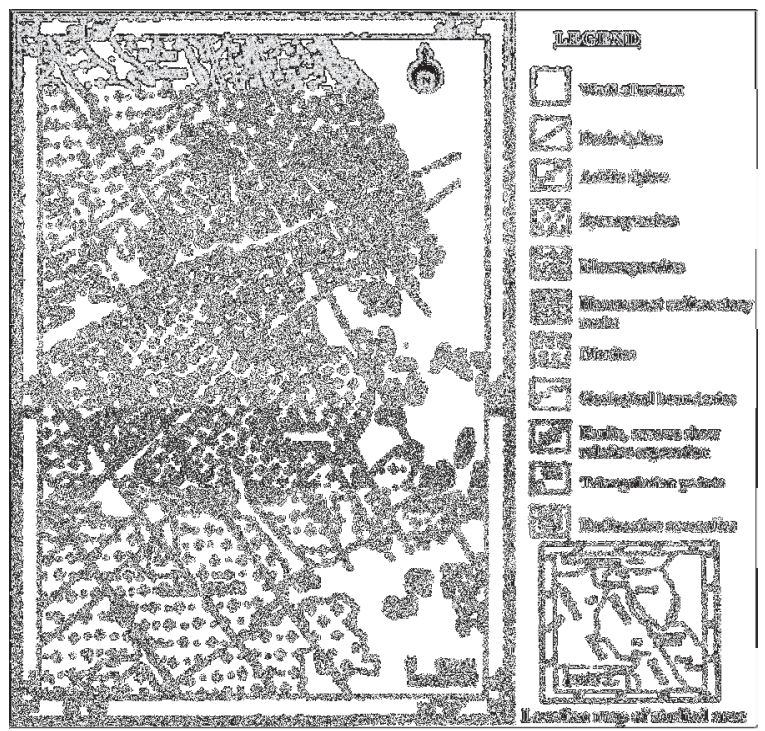

Fig.1 : Geologic map of the studied area

as follows: Diorites; Hammamat sedimentary rocks; younger granites with pegmatites and post granitic dykes and quartz veins. The detailed field description of the various rocks exposed in W. Faliq El-Sahl and W. Faliq El-Waar area is given in the following paragraphs.

Diorites are recorded chiefly in the extreme north-eastern part of the study area. They are also encountered as small-scattered exposures east of G. Abu Edam (Fig. I). The exposures of the diorites form a low hilly country rocks, well jointed, highly weathered showing certain degree of bleaching and decomposition. They show wide variation in their lithologic character and are heterogeneous even each outcrop. Diorites in the present area are dissected by major strike slip faults trending NW-SE. The rocks along fault zones are partly kaolinitized, highly hematitized, strongly sheared and enriched in potash feldspars. These diorites are found as small xenoliths ranging from $5 \mathrm{~cm}$ to about $25 \mathrm{~cm}$ in diameter within the younger granites and are also invaded by acidic and basic dykes.
Hammamat sedimentary rocks include wide lithologic varieties mainly represented by repeated successions of alternating beds of fine-grained siltstones, medium-grained greywackes and coarse-grained polymictic conglomeratic beds. They generally form moderate to low relief mountainous terrains with gentle slopes (Fig. 2). They are inter-veined by many dykes, mainly of acidic composition (Fig. 3).These sediments range in color from deep green to dark greyish green. Their bedding is easily recognized and detected in the field and is striking in the NNW-SSE direction and mainly dips from $15^{\circ}$ to $20^{\circ}$ toward the NE direction. The angle of dip mainly increases toward their contact with the granite masses, sometimes reaching up to $45^{\circ}$ at the contact zone. The Hammamat sedimentary rocks are slightly affected by contact metamorphism due to the intrusion of the younger granites and are well manifested by the presence of fissility along the contacts (Fig. 4). The polymictic conglomerates consist of rounded to subrounded, oval and/or lenticular pebbles of pre-existing rocks (Fig. 5). The color of these conglomeratic beds varies from light green to dark grey color, mainly depending on the type of rock clasts, constituents of the groundmass and alteration effects. 


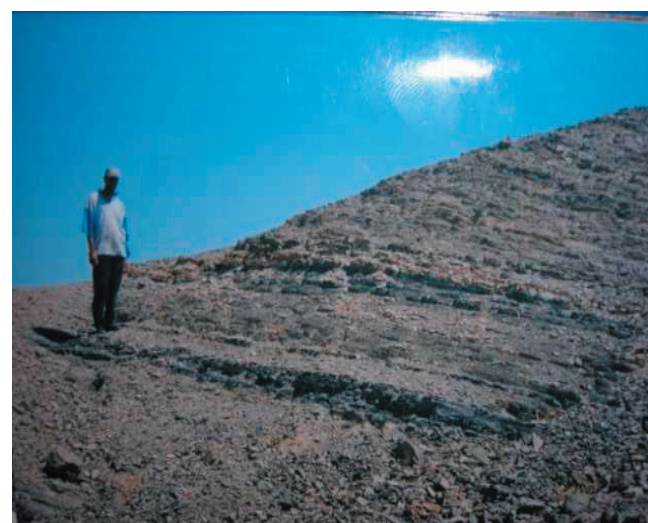

Fig. 2: General attitude of well bedded Hammamat sedimentary rocks following NNW-SSE direction

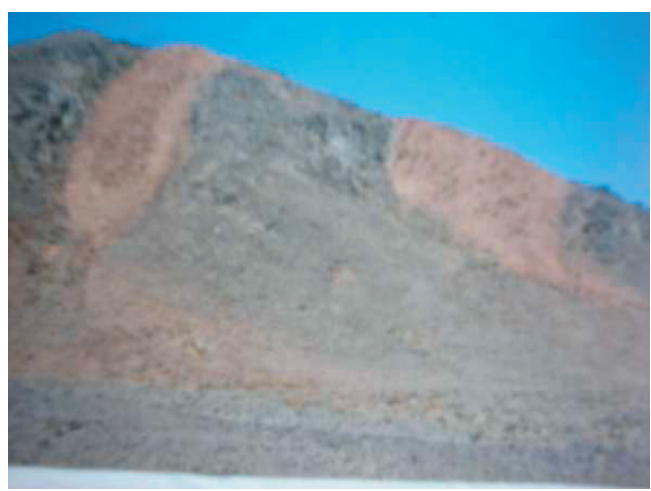

Fig. 3: Acidic dykes traversing Hammamat sedimentary rocks

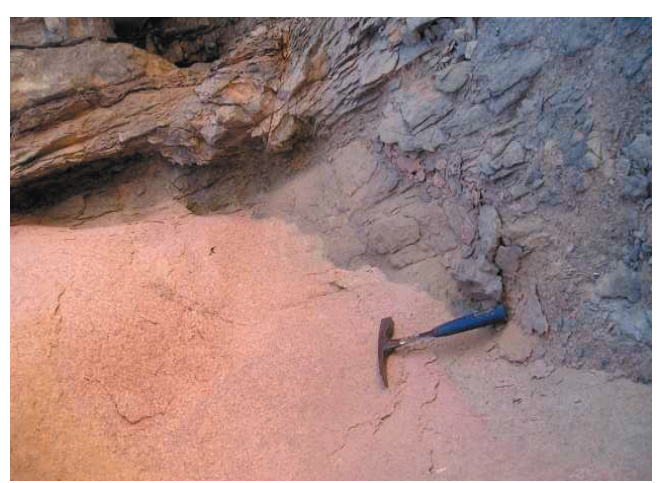

Fig. 4: Fissile Hammamat sedimentary rocks due to the intrusion of the granites

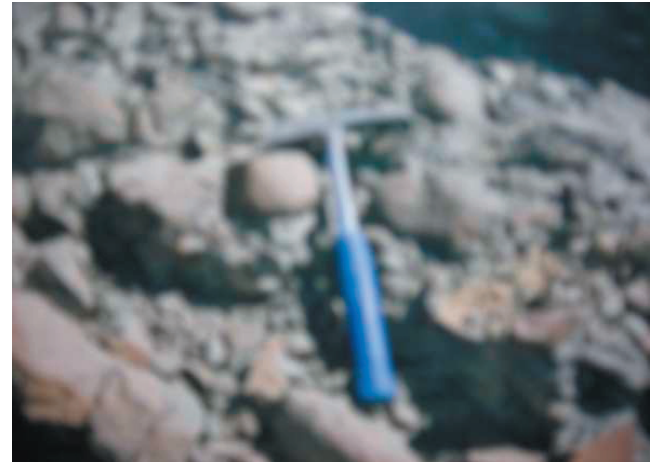

Fig. 5: Subrounded to lenticular pebbles forming the coarse-graind polymictic conglomerate beds of Hammamt sedimentary rocks

The younger granites are widely distributed forming the major suite of the basement rocks in the study area intruding all the pre-existing rocks. The younger granites are considered to be the most important rock type in the north tectonic domain Eastern Desert, for its radioactivity as they host most of the uranium occurrences (Salman et. al., 2005 and Shalaby et al., 2009).

The younger granites recorded in the area form moderate to high mountains with rough topographic outcrops possessing rounded to sub-rounded outlines. They are commonly massive and easily distinguished in the field from the surrounding country rocks by its distinctive color. The color ranges from pinkish white to pink and turns to reddish pink when they are stained with hematite along shear zones. Sheet structure is an obvious feature particularly along the marginal slopes of the plutons, as a result of load release. These younger granites are represented by two magmatic outcrops characterized by their different petrological characteristic. They are represented by monzogranites and syenogranite.

Monzogranites are situated at the northwestern corner of the study area forming Gabal Abu Edam and extend southward forming G. Abu Zogata surrounding the syenogranite of G. AlLuman. This rock type intrude the diorite rocks with sharp intrusive contact in the northern part and show well marked exfoliation (sheet struc- 
ture) essentially controlled by the topographic surfaces of the rocks (Fig. 6). These granites are characterized by their peculiar columnar type of joints, bearing many diorite xenoliths (of different shape and diameter), pinkish white in color, medium to coarse-grained and are devoid of mineralized pegmatites. These granites are traversed by a large number of parallel dykes mainly trending in the NE-SW direction (Fig.7), predominantly of basic composition, ranging from basaltic to doleritic as well as some acidic granite porphyry dykes. They are cut by major strike slip faults chiefly trending in NW-SE and NNW-SSE directions.

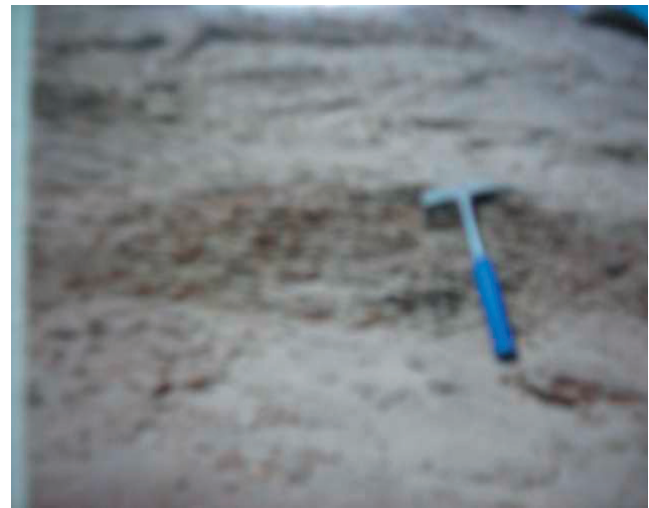

Fig. 6: Exfoliation (Sheet structure) in monzogranites

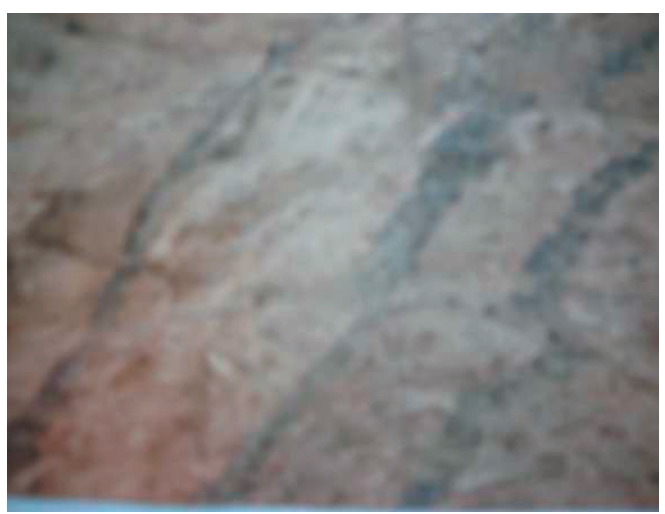

Fig. 7: Dykes of long extension running in subparallel sets in monzogranites
Syenogranites cover most of the central and eastern parts of the mapped area forming G. Al-Luman and the main rocks exposed in W. Faliq El-Sahl and W. Faliq El-Waar. Several wide wadis cross these granites and separate the hill masses from each other such as of W. Faliq El-Sahl and W. Faliq El-Waar and their tributaries. This type forms moderate highly serrated hills of bright reddish pink color. The red color is essentially due to the high content of potash feldspars stained by secondary red hematitic materials along their joints in particulars. The rocks are commonly medium- to coarse- grained, the grain size increases from medium along the margin to coarse toward the center of the masses. They are mainly composed of quartz and orthoclase perthite with subordinate plagioclase; rich in quartz and potash feldspars but poor in mafics. These granites intrude the monzogranites and stand against with sharp contact. Apophyses and tongues in some parts of the monzogranites and the Hammamat sediments exist. The latter are affected by the intrusion of these granites, causing slight metasomatic alteration and that changed in the attitude of their bedding. Sometimes, the Hammamat sediments occur as roof-pendants hanging over these granites especially along the eastern border (Fig. 8). On the other hand, these granites are invaded by high density of parallel basic and acidic dykes forming prominent high back bones trending NE-SW. Some of the peripheral parts show the cavernous type of weathering defined by Raguin (1965) as taffoni weathering (Fig. 9).

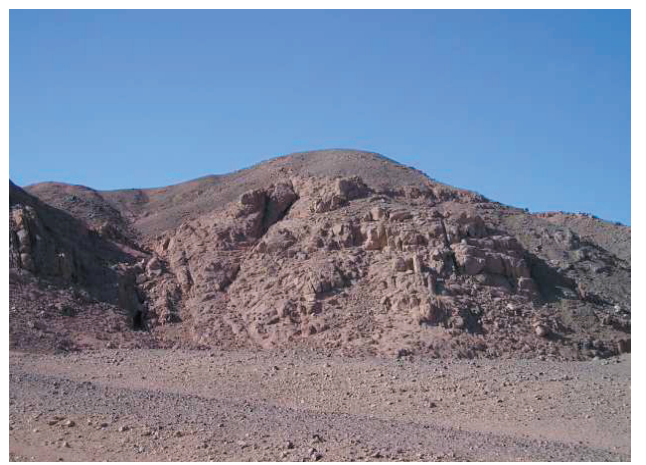

Fig. 8: Roof-pendant of Hammamat sedimentary rocks overlying the syenogranites 


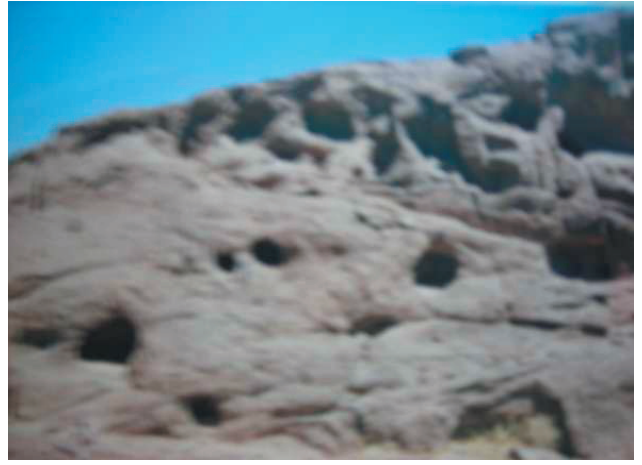

Fig. 9: Taffoni weathering in syenogranites

Both types of the younger granites are well jointed and dissected by numerous faults and shear zones. The granites at these shear zones become highly hematitized and acquire reddish pink to red color and are traversed by numerous quartz veins and abundant aplite dykes especially at their elevated parts.

Pegmatites are found as a number of small lenticular or irregular bodies. Sometimes they occur as pockets (Fig. 10) rather than being vein-like bodies aligned along some of the fault zones (Fig. 11). They are of limited extension, not exceeding $6 \mathrm{~m}$ in length and $1 \mathrm{~m}$ in width. In the study area the anomalous pegmatites are associated with syenogranites and exhibit sharp contact with them. They are mostly located at the peripheral parts of the granitic masses at different topographic levels.

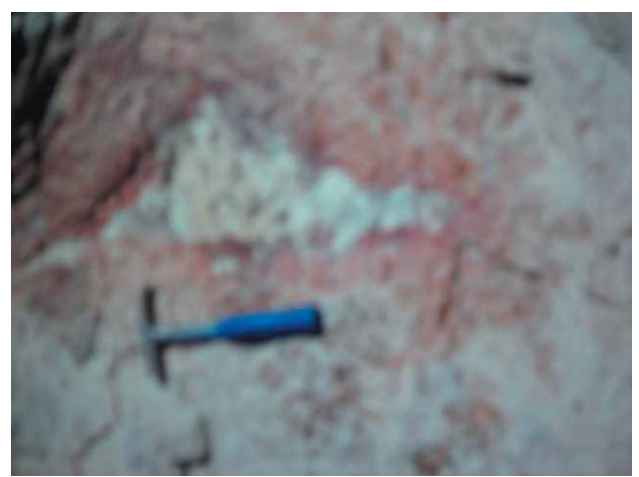

Fig.10: Pegmatite pockets recorded in syenogranites

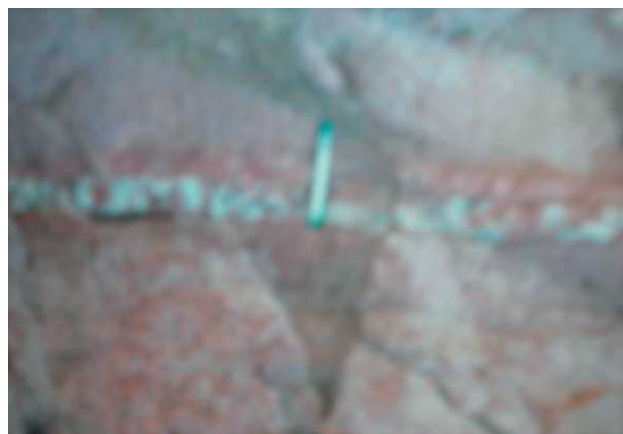

Fig.11: Pegmatite vein-like body traversing the syenogranites

The pegmatites are more resistant to erosion, with white or buff color on the fresh surface and brownish to reddish brown on the weathered surface due to their common impregnation with hematite. They are generally composed of extremely coarse-grained milky quartz and reddish buff orthoclase as the chief potash feldspar with few flaky mica and iron oxides. These pegmatites are generally unzoned, where no regular zonation of quartz and orthoclase. Some pegmatite pockets, especially those associated with shear zones are cracked and intensely stained with hematite. The pegmatites mark the close of the magmatic and pegmatitic phases of these granitic plutons.

The main fault trends cutting in the study area; in decreasing order of abundance are NNW-SSE, NW-SE, NE-SW and NNE-SSW (Fig. 12). W. Faliq El-Sahl and W. Faliq ElWaar younger granites are dissected by four major sets of joints, in decreasing order of abundance, striking NW-SE, NE-SW, NNWSSE and ENE-WSW (Fig. 13).

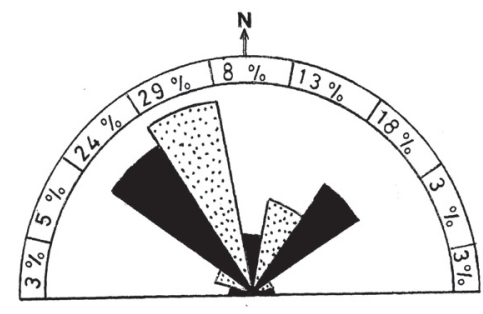

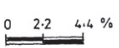

Fig.12: Rose diagram of the main directional trends of 42 fault lines in the granites according to their number proportion 


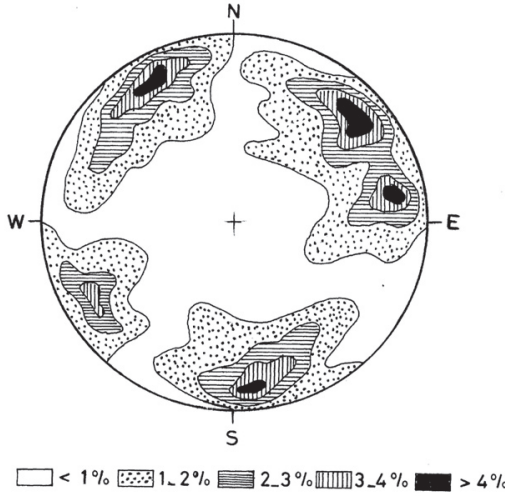

Fig.13: Contour diagram of 110 joint poles in the granites plotted on a lower hemisphere

The post granitic dykes of the studied area are mainly represented by dyke swarms ranging in composition from acidic, intermediate to basic; in addition to some veins which comprise feldspars and quartz. These dykes intersect all the rock types starting from the diorites to the younger granites. These dykes usually run in parallel to sub-parallel sets controlled by the predominating faults of the area especially those trending in the NE-SW direction and have a vertical to sub-vertical dip. They range in thickness from $0.5 \mathrm{~m}$ to $10 \mathrm{~m}$ and can be traced for tens of kilometers. These post granitic dykes can be chronologically arranged from older to younger as follows:1) Acidic dykes include granite porphyries; aplites and pegmatites., 2) Intermediate dykes include andesites., and 3) Basic dykes include dolerites and basalts.

\section{PETROGRAPHY}

In the present work, twenty representative thin sections were studied for the petrographic description of the younger granites and modal composition (Table 1), plotted on Q-A-P ternary diagram of Streckeisen (1976). The petrographic studies revealed that the studied younger granites are classified into two main varieties, monzogranite and syenogranite (Fig. 14).

The monzogranites are medium- to coarsegrained, equigranular, hypidiomorphic rocks
Table 1: The modal analyses of the studied granites

\begin{tabular}{|c|c|c|c|c|c|c|c|c|c|c|}
\hline \multirow{2}{*}{$\begin{array}{l}\text { Rock type } \\
\& \text { sp. o. }\end{array}$} & \multicolumn{6}{|c|}{ G.Abu Zagata monzogranites } & \multicolumn{4}{|c|}{ G. Al-Luman sy̧enogranites } \\
\hline & 1 & 2 & 3 & 4 & 5 & 6 & 7 & 8 & 9 & 10 \\
\hline Locality & \multicolumn{10}{|c|}{ W. Faliq El-Sahl } \\
\hline Quartz & 40.0 & 37.9 & 38.4 & 35.5 & 33.0 & 38.4 & 37.2 & 36.9 & 35.0 & 30.0 \\
\hline Perthite & 20.1 & 22.0 & 26.4 & 20.0 & 22.0 & 26.4 & 42.6 & 44.4 & 40.0 & 40.0 \\
\hline Plagioclase & 29.6 & 28.7 & 27.7 & 30.0 & 33.0 & 27.7 & 15.2 & 13.1 & 20.0 & 15.0 \\
\hline Mica & 7.7 & 8.0 & 6.5 & 9.5 & 8.0 & 6.5 & 1.2 & 1.1 & 3.1 & 8.2 \\
\hline $\begin{array}{l}\text { Accessories } \\
\text { and } \\
\text { opaquues }\end{array}$ & 2.6 & 3.5 & 1.1 & 5.0 & 6.0 & 1.1 & 3.5 & 4.5 & 1.9 & 6.8 \\
\hline Rock type & \multicolumn{6}{|c|}{ G. Abu Edam monzogranites } & \multicolumn{4}{|c|}{ G. Abu Edam syenogranites } \\
\hline \& sp. No. & 11 & 12 & 13 & 14 & 15 & 16 & 17 & 18 & 19 & 20 \\
\hline Locality & W. Faliq & I-Waar & & & & & & & & \\
\hline Quartz & 41.2 & 42.5 & 40.4 & 40.0 & 37.0 & 38.7 & 38.0 & 41.1 & 30.0 & 33.0 \\
\hline Perthite & 25.7 & 29.0 & 29.3 & 35.0 & 30.0 & 45.0 & 43.6 & 38.4 & 45.0 & 43.0 \\
\hline Plagioclase & 25.0 & 20.1 & 19.9 & 20.0 & 23.0 & 12.6 & 13.0 & 14.7 & 15.0 & 20.0 \\
\hline Mica & 6.0 & 6.0 & 6.6 & 3.1 & 6.6 & 1.3 & 1.4 & 1.1 & 5.1 & 3.0 \\
\hline $\begin{array}{l}\text { Accessories } \\
\text { and } \\
\text { opaques }\end{array}$ & 2.0 & 2.5 & 3.7 & 1.8 & 3.4 & 2.5 & 3.9 & 4.6 & 4.9 & 2.0 \\
\hline
\end{tabular}

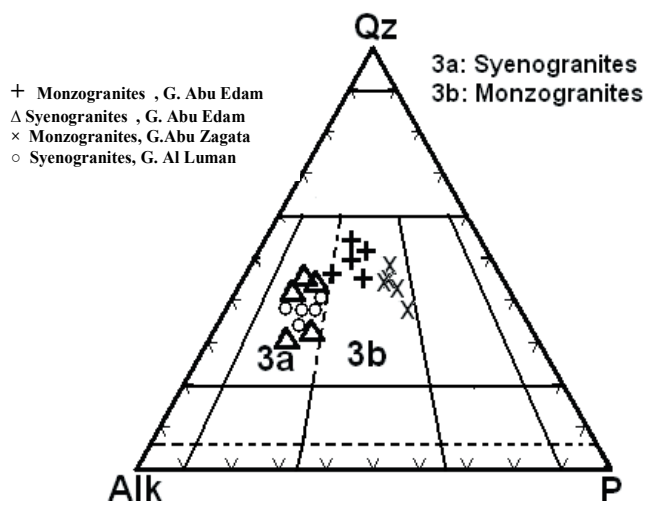

Fig. 14 : Q-A-P modal ternary plot according to Streckeisen, 1976

and mainly composed of perthitic orthoclase, quartz, plagioclase, biotite and hornblende in small amounts as essential minerals while sphene, apatite, zircon, fluorite and iron oxides as accessory and secondary minerals. The biotite is chloritized along its boundaries and shows iron oxides along cleavage. 
The syenogranites are fine- to mediumgrained, hypidiomorphic rocks, and are essentially composed of orthoclase and microcline perthites, quartz, plagioclase, biotite and muscovite. The accessory and secondary minerals are zircon, sphene, apatite, epidote, fluorite and iron oxides. Small zircon crystals as inclusions are surrounded by haloes due to presence of radioactive minerals in its crystal lattices.

\section{GEOCHEMISTRY}

Eighteen samples from the studied granites of G. Abu Zagata monzogranites, G. AlLuman syenogranites, G. Abu Edam monzogranites and G. Abu Edam syenogranites are selected for chemical analysis to identify their geochemical behaviour, petrochemical characteristics, magma type and tectonic setting (nine samples from each part of the pluton). The chemical analysis for the major oxides (wt $\%$ ) and the trace elements (ppm) were done by using wet chemical analysis technique of Shapiro and Brannock (1962) and XRF technique, respectively in the Department of Chemical Analysis of the Nuclear Materials Authority of Egypt.

The chemical analysis for major oxides and trace elements as well as some geochemical ratios for the studied monzogranites and syenogranites are shown in Table (2). $\mathrm{Rb}, \mathrm{Nb}$, $\mathrm{Zr}$ and $\mathrm{F}^{-}$are low in monzogranite compared to the syenogranite of Wadi Faliq El Sahl and vice versa for $\mathrm{CaO}, \mathrm{MgO}, \mathrm{FeO}, \mathrm{Ba}$ and $\mathrm{Sr}$. Such geochemical characteristics are valued in the Faliq El Waar granites for $\mathrm{Rb}, \mathrm{Nb}, \mathrm{Zr}$ and $\mathrm{F}$

\section{Geochemical Classification and Petrogenesis}

On the Ab-Or-An ternary diagram of O'Connor (1965), the studied rock amples plot in the granite field (Fig. 15).

The low $\mathrm{K} / \mathrm{Rb}$ ratios and the high $\mathrm{K} / \mathrm{Ba}$ ratios may suggest advanced degree of magmatic differentiation and contribution of sialic crustal material. The $\mathrm{K} / \mathrm{Rb}$ ratios for the studied granites (Table 2) range from 183 to 432
Table 2: Major element oxides ( $\mathrm{wt} \%$ ) and trace elements ( $\mathrm{ppm}$ ) data and some calculated geochemical ratios of the studied granitic plutons

\begin{tabular}{lccccccccc}
\hline Rock type & \multicolumn{3}{c}{ G.Abu Zagata monzogranites } & \multicolumn{4}{c}{ G. Al-Luman syenogranites } \\
$\&$ sp.No. & 1 & 2 & 3 & 4 & 5 & 6 & 7 & 8 & 9 \\
\hline \multicolumn{3}{c}{ W. Faliq El Sahl } & & & & & &
\end{tabular}

Major oxides ( $w$ \% $\%$ )

$\begin{array}{llllllllll}\mathrm{SiO}_{2} & 72.86 & 72.64 & 72.68 & 72.71 & 73.94 & 74.10 & 74.20 & 74.12 & 74.16\end{array}$ $\begin{array}{llllllllll}\mathrm{TiO}_{2} & 00.19 & 00.21 & 00.23 & 00.22 & 00.12 & 00.10 & 00.12 & 00.14 & 00.11\end{array}$ $\begin{array}{llllllllll} & 13.86 & 13.79 & 13.89 & 13.80 & 13.54 & 13.48 & 13.28 & 13.53 & 13.50\end{array}$ $\begin{array}{lllllllllll}\mathrm{Al}_{2} \mathrm{O}_{3} & 13.86 & 13.79 & 13.89 & 13.80 & 13.54 & 13.48 & 13.28 & 13.53 & 13.50\end{array}$ $\begin{array}{lllllllllll}13.86 & 13.79 & 13.89 & 13.80 & 13.54 & 13.48 & 13.28 & 13.53 & 13.50\end{array}$

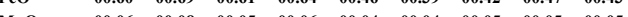

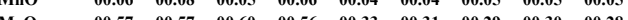
$\begin{array}{lllllllllll}\text { MgO } & 00.57 & 00.57 & 00.60 & 00.56 & 00.33 & 00.31 & 00.29 & 00.30 & 00.28\end{array}$ $\begin{array}{lllllllllll}\mathrm{CaO} & 01.60 & 01.76 & 01.78 & 01.56 & 00.73 & 00.78 & 00.80 & 00.81 & 00.80\end{array}$ $\begin{array}{llllllllll}\mathrm{Na}_{2} \mathrm{O} & 03.66 & 03.78 & 03.64 & 03.84 & 03.89 & 03.83 & 03.88 & 03.82 & 03.84\end{array}$ $\begin{array}{llllllllll}\mathrm{K}_{2} \mathrm{O} & 04.01 & 04.02 & 04.03 & 04.10 & 04.38 & 04.40 & 04.42 & 04.41 & 04.42\end{array}$ $\begin{array}{llllllllll}\mathrm{P}_{2} \mathrm{O}_{5} & 00.08 & 00.11 & 00.10 & 00.09 & 00.12 & 00.09 & 00.11 & 00.09 & 00.09\end{array}$ $\begin{array}{llllllllll}\text { L.O.I. } & 00.90 & 00.71 & 00.68 & 00.89 & 00.80 & 00.90 & 00.90 & 00.80 & 00.80\end{array}$ $\begin{array}{llllllllll}\text { Total } & 99.931 & 99.94 & 99.92 & 99.97 & 99.93 & 99.94 & 99.95 & 99.96 & 99.92\end{array}$ Trace elements (ppm)

$\begin{array}{llllllllll}\text { Rb } & 87.00 & 84.0 & 90.00 & 81.00 & 194.0 & 188.0 & 188.0 & 182.0 & 177.0\end{array}$ $\begin{array}{llllllllllll}512.0 & 441.0 & 464.0 & 429.0 & 387.0 & 396.0 & 402.0 & 413.0 & 411.0\end{array}$ $\begin{array}{llllllllllll}512.0 & 44.0 & 464.0 & 429.0 & 387.0 & 396.0 & 402.0 & 413.0 & 411.0\end{array}$ $\begin{array}{llllllllll}118.0 & 130.0 & 11.0 & 122.0 & 82.00 & 96.00 & 91.00 & 81.00 & 83.00\end{array}$ $\begin{array}{llllllllllll}82.00 & 67.00 & 79.00 & 73.00 & 102.0 & 121.0 & 106.0 & 93.00 & 100.0\end{array}$ $\begin{array}{llllllllll}161.0 & 148.0 & 152.0 & 152.0 & 219.0 & 236.0 & 232.0 & 204.0 & 212.0\end{array}$ $\begin{array}{llllllllll}29.00 & 36.00 & 22.00 & 32.00 & 28.00 & 37.00 & 31.00 & 31.00 & 33.00\end{array}$

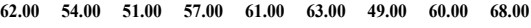
$\begin{array}{lllllllll}12.00 & 11.50 & 11.00 & 10.00 & 23.00 & 28.00 & 26.00 & 20.00 & 20.50\end{array}$ Geochemical ratios

$\begin{array}{llllllllll}\mathrm{K} / \mathrm{Rb} & 384.0 & 399.0 & 373.0 & 422.0 & 184.0 & 195.0 & 196.0 & 201.0 & 208.0\end{array}$ $\begin{array}{llllllllll}\mathrm{K} / \mathrm{Ba} & 65.23 & 75.96 & 72.41 & 79.72 & 94.32 & 92.68 & 91.54 & 88.86 & 89.54\end{array}$ $\begin{array}{llllllllll}\mathrm{Rb} / \mathrm{Sr} & 0.737 & 0.646 & 0.756 & 0.663 & 2.365 & 1.958 & 2.065 & 2.246 & 21.16\end{array}$ $\begin{array}{llllllllll}\mathrm{Zr} / \mathrm{Sr} & 1.364 & 1.138 & 1.277 & 1.245 & 2.670 & 2.458 & 2.549 & 2.518 & 2.554\end{array}$

\begin{tabular}{lcccccccccc}
\hline Rock type & \multicolumn{3}{c}{ G.Abu Zagata monzogranites } & \multicolumn{3}{c}{ G. Al-Luman syenogranites } \\
$\&$ sp. No. & 10 & 11 & 12 & 13 & 14 & 15 & 16 & 17 & 18 \\
\hline \multicolumn{3}{c}{ W. Faliq El Waar } & & & & & &
\end{tabular}

Major oxides (wt \%)

$\begin{array}{llllllllll}\mathrm{SiO}_{2} & 72.70 & 72.68 & 72.82 & 72.73 & 72.62 & 74.17 & 74.14 & 73.88 & 74.18\end{array}$ $\begin{array}{llllllllll}\mathrm{SiO}_{2} & 72.70 & 72.68 & 72.82 & 72.73 & 72.62 & 74.17 & 74.14 & 73.88 & 74.18 \\ \mathrm{TiO}_{2} & 00.20 & 00.19 & 00.22 & 00.21 & 00.23 & 00.13 & 00.14 & 00.15 & 00.11\end{array}$ $\begin{array}{llll}0.14 & 0.15 & 0.11\end{array}$ $\begin{array}{lllllllllllll}\mathrm{Al}_{2} \mathrm{O}_{3} & 13.90 & 13.74 & 13.77 & 13.80 & 13.82 & 13.44 & 13.45 & 13.52 & 13.38\end{array}$ $\begin{array}{llllllllllll}\mathrm{Fe}_{2} \mathrm{O}_{3} & 01.56 & 01.53 & 01.59 & 01.58 & 01.60 & 01.52 & 01.53 & 01.46 & 01.50\end{array}$ $\begin{array}{lllllllllll}\mathrm{FeO} & 00.67 & 00.66 & 00.61 & 00.62 & 00.54 & 00.47 & 00.45 & 00.47 & 00.44\end{array}$ $\begin{array}{llllllllll}\mathrm{MnO} & 00.05 & 00.06 & 00.03 & 00.04 & 00.06 & 00.03 & 00.03 & 00.06 & 00.05\end{array}$ $\begin{array}{llllllllll}\mathrm{MgO} & 00.53 & 00.54 & 00.52 & 00.53 & 00.56 & 00.28 & 00.32 & 00.29 & 00.32\end{array}$ $\begin{array}{llllllllll}\mathrm{CaO} & 01.67 & 01.65 & 01.64 & 01.68 & 01.58 & 00.80 & 00.76 & 00.77 & 00.78\end{array}$ $\begin{array}{llllllllll}\mathrm{Na}_{2} \mathrm{O} & 03.64 & 03.72 & 03.80 & 03.81 & 03.82 & 03.82 & 03.80 & 03.84 & 03.88\end{array}$ $\begin{array}{llllllllll}\mathrm{K}_{2} \mathrm{O} & 04.11 & 04.04 & 04.02 & 04.05 & 04.09 & 04.40 & 04.46 & 04.50 & 04.52\end{array}$ $\begin{array}{llllllllll}\mathrm{P}_{2} \mathrm{O}_{5} & 00.09 & 00.12 & 00.06 & 00.09 & 00.11 & 00.10 & 00.09 & 00.09 & 00.08\end{array}$ $\begin{array}{llllllllll}\text { L.O.I. } & 00.80 & 00.94 & 00.86 & 00.81 & 00.90 & 00.80 & 00.80 & 00.90 & 00.70\end{array}$

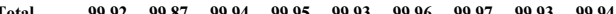

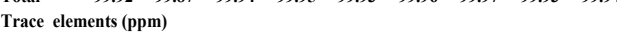
$\begin{array}{llllllllll}\text { Trace elements (ppm) } & & & & & & & \\ \mathrm{Rb} & 93.00 & 84.00 & 81.00 & 87.00 & 79.00 & 197.0 & 202.0 & 205.0 & 191.0\end{array}$ $\begin{array}{llllllllll}\mathrm{Rb} & 93.00 & 84.00 & 81.00 & 87.0 & 79.00 & 197.0 & 202.0 & 205.0 & 191.0 \\ \mathrm{Ba} & 418.0 & 452.0 & \mathbf{5 0 2 . 0} & 421.0 & 437.0 & 411.0 & 412.0 & 378.0 & 423.0\end{array}$ $\begin{array}{llllllllll}\mathrm{Ba} & 418.0 & 452.0 & 502.0 & 421.0 & 437.0 & 411.0 & 412.0 & 378.0 & 423.0 \\ \mathrm{Sr} & 111.0 & 127.0 & 113.0 & 118.0 & 114.0 & 107.0 & 92.00 & 89.00 & 92.00\end{array}$ $\begin{array}{llllllllll}\mathrm{Sr} & 111.0 & 127.0 & 113.0 & 118.0 & 114.0 & 107.0 & 92.00 & 89.00 & 92.00 \\ \mathrm{Nb} & 81.00 & 74.00 & \mathbf{6 8 . 0 0} & \mathbf{8 5 . 0 0} & \mathbf{7 2 . 0 0} & \mathbf{1 2 8 . 0} & \mathbf{1 2 8 . 0} & \mathbf{9 2 . 0 0} & \mathbf{1 2 1 . 0}\end{array}$ $\begin{array}{llllllllll}\mathrm{Zr} & 143.0 & 135.0 & 146.0 & 154.0 & 152.0 & 243.0 & 263.0 & 209.0 & 224.0\end{array}$ $\begin{array}{llllllllll}Y & 32.00 & 25.00 & 21.00 & 34.00 & 27.00 & 36.00 & 43.00 & 31.00 & 38.00\end{array}$ $\begin{array}{llllllllll}\mathrm{Pb} & \mathbf{6 4 . 0 0} & \mathbf{5 7 . 0 0} & \mathbf{4 9 . 0 0} & \mathbf{6 5 . 0 0} & \mathbf{5 3 . 0 0} & \mathbf{6 9 . 0 0} & \mathbf{7 2 . 0 0} & \mathbf{6 4 . 0 0} & \mathbf{5 3 . 0 0}\end{array}$ $\begin{array}{lllllllll}9.500 & 8.000 & 10.00 & 11.00 & 12.00 & 29.00 & 30.00 & 20.00 & 27.00\end{array}$

\section{Geochemical ratios}

$\begin{array}{llllllllll}\mathrm{K} / \mathrm{Rb} & 368.0 & 401.0 & 414.0 & 387.0 & 432.0 & 186.0 & 184.0 & 183.0 & 197.0\end{array}$ $\begin{array}{llllllllll}\mathrm{K} / \mathrm{Ba} & 81.82 & 74.56 & 66.73 & 80.05 & 78.03 & 89.29 & 90.29 & 99.21 & 89.13\end{array}$ $\begin{array}{llllllllll}\mathrm{Rb} / \mathrm{Sr} & 0.837 & 0.677 & 0.716 & 0.737 & 0.692 & 1.841 & 2.195 & 2.303 & 2.076\end{array}$ $\begin{array}{llllllllll}1.288 & 1.062 & 1.292 & 1.305 & 1.333 & 2.271 & 2.858 & 2.348 & 2.434\end{array}$ \begin{tabular}{lllllllllll}
$\mathrm{Ba} / \mathrm{Rb}$ & 4.494 & 5.380 & 6.197 & 4.839 & 5.531 & 2.086 & 2.039 & 1.843 & 2.214 \\
\hline
\end{tabular} 


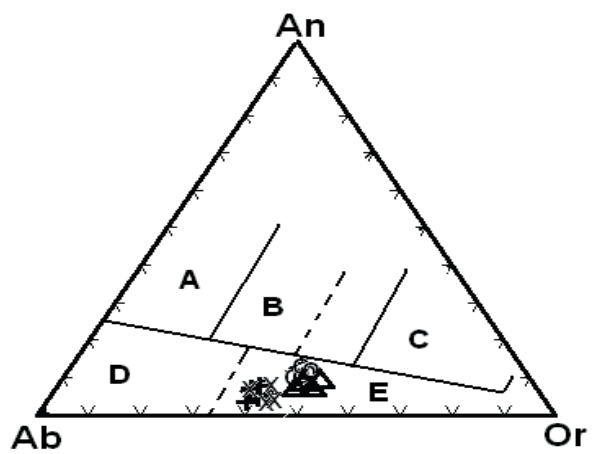

Fig. 15: Ab-Or-An diagram (O'Connor, 1965); Fields: A, Tonalite, B, Granodiorite, C, Adamlite, D, Trandhjemite, E, Granites , Symbols as in Fig. 14

which is much lesser than Heier's values (700 to 1500) suggesting that the granites are not from upper mantle materials (Heier, 1973). Significant contribution of sialic crustal materials is the most probable (Dostal and Chatterjee, 2000).

The $\mathrm{K} / \mathrm{Ba}$ (Table 2) ratios for the studied granites range from 65 to 99 which are much higher than Mason's ratio (65, Mason 1966) supporting advanced degree of magmatic differentiation and contribution from sialic crustal materials.

The $\mathrm{Zr} / \mathrm{Sr}$ ratio increases with increasing differentiation (Hall and Walsh, 1969), and also a high $\mathrm{Zr} / \mathrm{Sr}$ ratio $(>1.65)$ for the uraniferous granite with presence of small amounts of dispersed fluorite in granites. This concept is in agreement with the geochemical data and the petrographical investigations of the studied syenogranites of the two plutons favoring its uraniferous character.

\section{Magma Type and Tectonic Setting}

On the $\mathrm{Na}_{2} \mathrm{O}+\mathrm{K}_{2} \mathrm{O}$ versus $\mathrm{SiO}$, variation diagram of Irvine and Baragar (1971), both types of the studied granites are plotted in the subalkaline field (Fig.16). The analyzed granite samples are plotted in the peraluminous field of Shand (1951), (Fig.17).

On the $\mathrm{Al}_{2} \mathrm{O}_{3}$ versus $\mathrm{SiO}_{2}$ diagram of Maniar and Piccoli (1989), the samples of studied granites are plotted in the post orogenic field
(Fig.18). Rogers et al. (1978) concluded that the younger granites of the Nubian Shield in Egypt are an example of the post-orogenic granitoids.

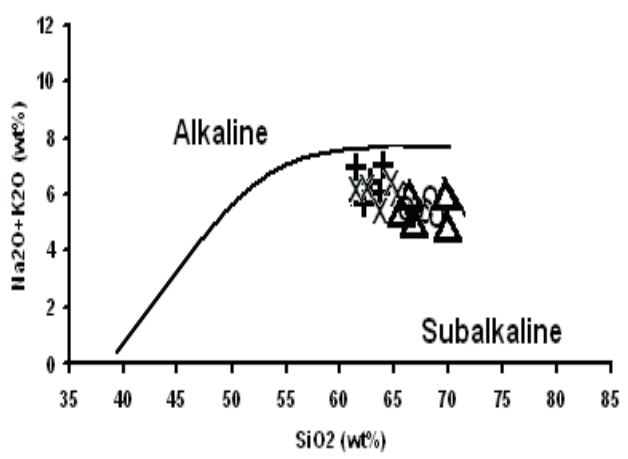

Fig. 16: $\left(\mathrm{Na}_{2} \mathrm{O}+\mathrm{K}_{2} \mathrm{O}\right)$ vs $\mathrm{SiO}_{2}$ variation diagram (Irvine and Braragar, 1971), Symbols as in Fig.14

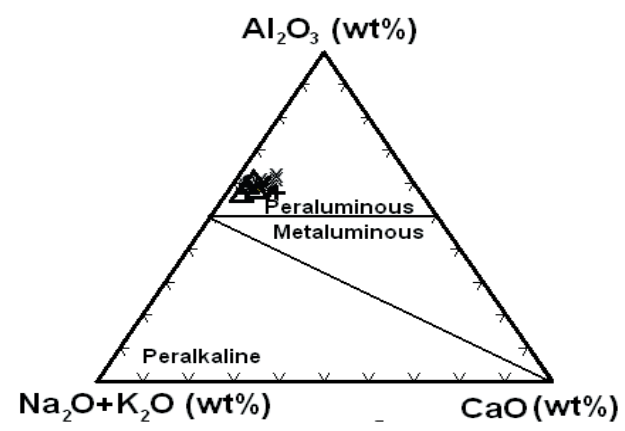

Fig. 17: Alk-CaO- $\mathrm{Al}_{2} \mathrm{O}_{3}$ diagram (Shand,1951), Symbols as in Fig.14

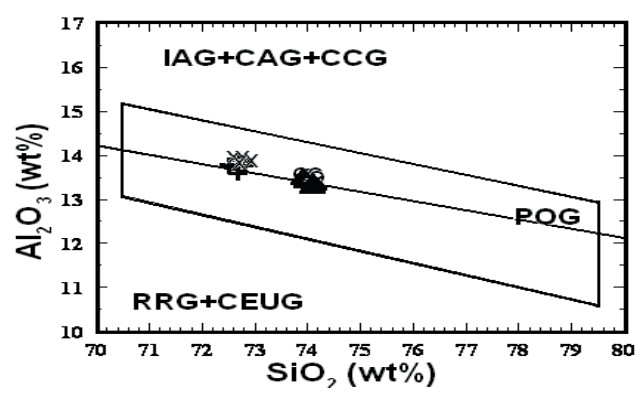

Fig. 18: $\mathrm{SiO}_{2}$ vs $\mathrm{Al}_{2} \mathrm{O}_{3}$ diagram (Maniar and Piccoli, 1989), Symbols as in Fig.14 
On the $\mathrm{Rb}$ versus $\mathrm{Sr}$ variation diagram of Condie (1973), the studied granites are intruded in a crust of thickness between $22 \mathrm{~km}$ and $30 \mathrm{~km}$ with $\mathrm{Rb} / \mathrm{Sr}$ ratios range from 0.1 to 1.0 during crystallization of monzogranites but $\mathrm{Rb} / \mathrm{Sr}$ ratios range from 1.0 to 10.0 during crystallization of syenogranites. (Fig.19). Cox et al. (1979) suggested that the granitoid rocks, which intrude crust of thickness more than $20 \mathrm{~km}$ crystallize at temperatures ranging from $800^{\circ}$ to $850^{\circ} \mathrm{C}$ at water vapour pressure less than $3 \mathrm{~kb}$.

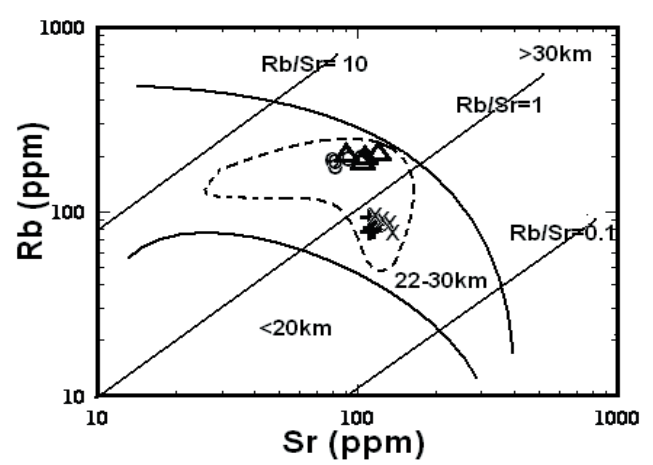

Fig. 19: Rb vs Sr diagram (Condi and Hunter, 1976), Dote area Egyptian younger granites according to Samaan, 2000 ,Symbols as in Fig.14

$\mathrm{The} \mathrm{Rb} / \mathrm{Sr}$ ratios are used to indicate the depth of magma generation within the crust by Condi and Hunter (1976). This ratio is greatly affected by the mineralogical composition of the residue after partial melting, whereas ratio increases by the presence of feldspars and decreases by presence of biotite in the residue (Hanson, 1978).

The $\mathrm{Rb} / \mathrm{Sr}$ variation diagram (Fig.19) shows that all studied younger granites are plotted in the area between $\mathrm{Rb} / \mathrm{Sr}$ ratio $10-0.1$ that crystallized under crustal thickness between 22 to $30 \mathrm{~km}$, and the analyzed granite samples are plotted in the field of the younger granites of Nubian Shield in Egypt field of Samaan (2000).

On the $\mathrm{Rb}-(\mathrm{Y}+\mathrm{Nb})$ relationships of Pearce et al. (1984), the studied younger granites plot in the within plate granite field as well as in the field of the Egyptian younger granites of the Nubian Shield given by Samaan (2000), (Fig.20).

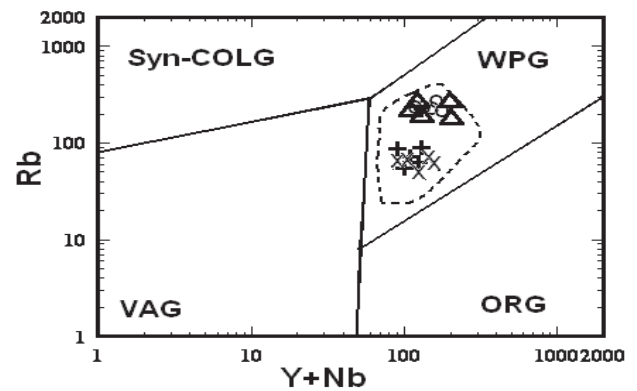

Fig. 20: Rb-Y+Nb diagram (Pearce, et al. 1984), Dote area Egyptian younger granites according to Samaan, 2000 ,Symbols as in Fig.14

From the previous interpretation of the granite relationships, there are no obvious differences between the monzogranites of $\mathrm{G}$. Abu Zagata and G. Abu Edam and the syenogranites of G. Al-Luman and G. Abu Edam in the studied area. The geochemical ratios of the studied younger granites show similarity to a great extent suggesting that these granites represent outcrops of one batholith and originated by magmatic differentiation of the same magma.

\section{RADIOACTIVITY.}

In the present work, systematic measurements of gamma radioactivity are carried out on the granites by using portable gamma ray spectrometer model UG-130 that displays the count rate in counts per second (cps), by means of the calibration. All the measurements were converted into unit of radioelement content (Ur). The field radioactivity level of the younger granites is much higher than the surrounding rocks. The syenogranites are also characterized by high radioactive levels ranging from 44 to $50 \mathrm{Ur}$ if compared to the monzogranites varying from 38 to $42 \mathrm{Ur}$.

Radiometric analyses are carried out at Laboratories of the Nuclear Materials Authority (NMA), Egypt (using quantitative gamma- 
ray spectrometry technique) being used to determine eU and eTh in part per million (ppm). The syenogranites have equivalent uranium content (eU) ranging from $14 \mathrm{ppm}$ to $19 \mathrm{ppm}$ and equivalent thorium content ( $\mathrm{eTh}$ ) ranging from $26 \mathrm{ppm}$ to $31 \mathrm{ppm}$, while the monzogranites have eU (7-11 ppm) and eTh (22-28 ppm). The obtained results of eU and eTh as well as the eTh/eU ratio values are given in Table (3). Table (3) : eU and eTh contents (ppm) as well as radiometric ratio (eTh / eU) of the studied monzo- and syenogranites of W. Faliq El-Sahl and W. Faliq El-Waar

\begin{tabular}{|c|c|c|c|c|c|}
\hline \multirow{2}{*}{\multicolumn{2}{|c|}{$\begin{array}{l}\text { Rock type } \\
\text { \& } \\
\text { Locality }\end{array}$}} & \multirow[t]{2}{*}{$\begin{array}{l}\text { Sp. } \\
\text { No. }\end{array}$} & \multicolumn{2}{|c|}{$\begin{array}{r}\text { Gamma ray } \\
\text { spectrometry }\end{array}$} & \multirow{2}{*}{$\begin{array}{r}\text { Radiometric } \\
\text { ratio } \\
\text { eTh/eU }\end{array}$} \\
\hline & & & $\mathbf{e U}$ & eTh & \\
\hline \multirow{11}{*}{ 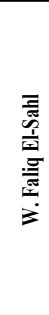 } & \multirow{6}{*}{ 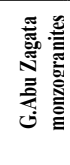 } & 1 & 8 & 25 & 3.13 \\
\hline & & 2 & 7 & 22 & 3.14 \\
\hline & & 3 & 8 & 23 & 2.88 \\
\hline & & 4 & 9 & 25 & 2.78 \\
\hline & & Av. & 8.00 & 23.75 & 2.98 \\
\hline & & 5 & 14 & 27 & 1.93 \\
\hline & \multirow{6}{*}{ 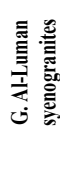 } & 6 & 15 & 27 & 1.80 \\
\hline & & 7 & 16 & 28 & 1.63 \\
\hline & & 8 & 17 & 29 & 1.71 \\
\hline & & 9 & 15 & 26 & 1.73 \\
\hline & & Av. & 15.40 & 27.40 & 1.76 \\
\hline \multirow{11}{*}{ 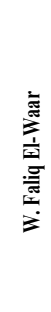 } & & 10 & 9 & 26 & 2.78 \\
\hline & \multirow{5}{*}{ 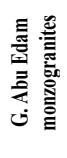 } & 11 & 11 & 27 & 2.36 \\
\hline & & 12 & 10 & 25 & 2.50 \\
\hline & & 13 & 9 & 27 & 3.00 \\
\hline & & 14 & 9 & 28 & 3.11 \\
\hline & & Av. & 9.60 & 26.60 & 2.75 \\
\hline & \multirow{5}{*}{ 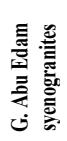 } & 15 & 19 & 31 & 1.63 \\
\hline & & 16 & 14 & 27 & 1.93 \\
\hline & & 17 & 18 & 31 & 1.72 \\
\hline & & 18 & 17 & 29 & 1.71 \\
\hline & & Av. & 17.00 & 29.50 & 1.75 \\
\hline
\end{tabular}

\section{Uranium Relationships}

$\mathrm{U}, \mathrm{Th}, \mathrm{Zr}, \mathrm{Nb}$ and $\mathrm{Rb}$ behave incompatibly in a granitic melt so that, where $U$ concentration is controlled by magmatic processes, these elements would be expected to increase (Cuney, 1984). The relationship between U and Th may indicate the enrichment or depletion of $U$ knowing that $T h$ is relatively stable during post magmatic processes. Normally, thorium is three times as abundant as uranium in granitic rocks (Rogers and Adams, 1969). When this ratio is disturbed, it indicates addition or leaching of uranium.

In the studied area, monzogranites show $\mathrm{eTh} / \mathrm{eU}$ ratios ranging from 2.36 to 3.14 with an average of 2.98 (normal value), but these values in syenogranites range from 1.63 to 1.93 with an average of 1.75 , suggesting addition of uranium. Accordingly, the studied syenogranites are considered as uraniferous granites. The wide variation in eTh/eU ratio in both monzogranites and syenogranites prefers the redistribution and addition or leaching of $\mathrm{U}$ after consolidation of the magma (Steenfelt, 1982; Pier, 1992 and Moharem, 1999). Along microfractures, joints and fault planes (Scheepers, 2000); involve many types of alteration such as kaolinatization and sericitization as well as hematitization (Shalaby and Moharem, 2008).

The geochemical data classified the studied syenogranites as uraniferous granites; all results are in a complete harmony with the description of uraniferous granites given by several authors. The main characters of uraniferous granites are: (1) two mica, peraluminous, red-pink, post orogenic granites (Cuney, 1984 and Abd El Monem et al., 1990); (2) highly differentiated granite with low $\mathrm{CaO}(<0.97$ $\%)$, low $\mathrm{Sr}(<100 \mathrm{ppm})$ and high $\mathrm{Rb}(>175$ ppm) contents as well as low $\mathrm{Na}_{2} \mathrm{O} / \mathrm{K}_{2} \mathrm{O}$ ratio values $(<1.11)$ given by Assaf et al.(1997); (3) $\mathrm{Zr} / \mathrm{Sr}$ ratio values more than 1.65 (Hall and Walsh, 1969); (4) eU / eTh ratios greater than 0.4 (Cambon, 1994); (5) the average U content is more than twice of Clarke value and $\mathrm{eTh} / \mathrm{eU}$ ratio is less than 3 (Darnley, 1982).

In this work, the plotting of eU against eTh (Fig.21) shows positive correlation between eU and eTh suggesting their increase with magmatic differentiation. The relationship of eU versus alkali elements $\left(\mathrm{Na}_{2} \mathrm{O}+\mathrm{K}_{2} \mathrm{O}\right.$ wt $\left.\%\right)$ show positive relation (Fig.22) indicating the incompatible behavior of the uranium during magmatic differentiation. This indicates that the magmatic processes play an important role of the primary uranium enrichment of these granites.

The relationship between eU-Zr show weak positive correlation for monzogranites, but in syenogranites it shows strong positive correlation (Fig.23), indicating uranium enrichment uncontrolled by primary magmatic 
processes but supporting that $\mathrm{U}$ was trapped in the accessory minerals as zircon (Pagel, 1982; London, 1992 and Scheepers and Rozendaal, 1995).

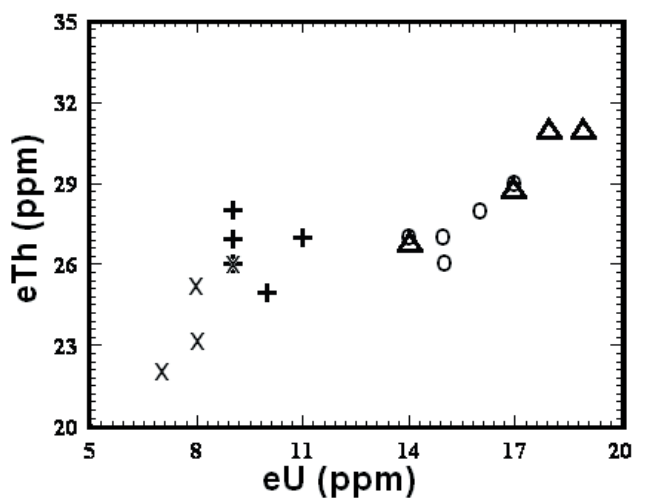

Fig. 21: eU-eTh variation diagram,Symbols as in Fig.14

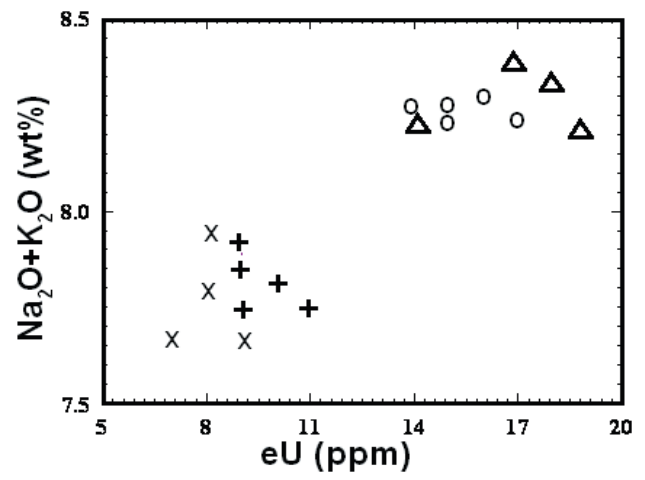

Fig. 22:eU-Alkalis $\left(\mathrm{Na}_{2} \mathrm{O}+\mathrm{K}_{2} \mathrm{Owt} \%\right.$ ) variation diagram,Symbols as in Fig.14

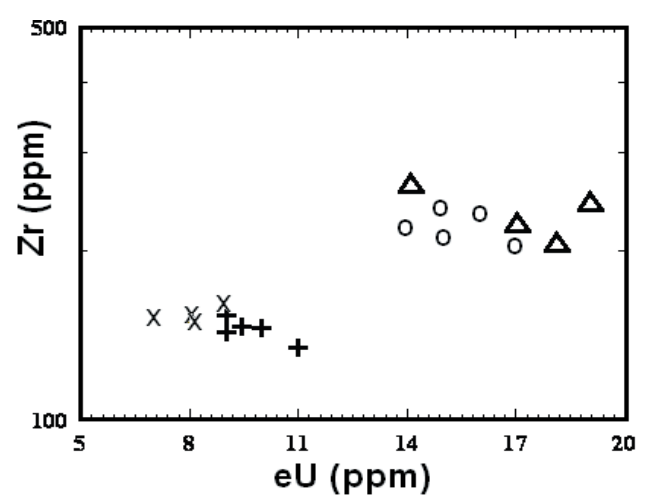

Fig. 23 : eU-Zr variation diagram, Symbols as in Fig.14
On the eU-F- variation diagram (Fig.24), the monzogranite samples show indefinite correlation, but in syenogranite samples show strong positive correlation indicating that uranium enrichment was mainly related to epigenetic processes and supporting trapping of $\mathrm{U}$ in fluorite.

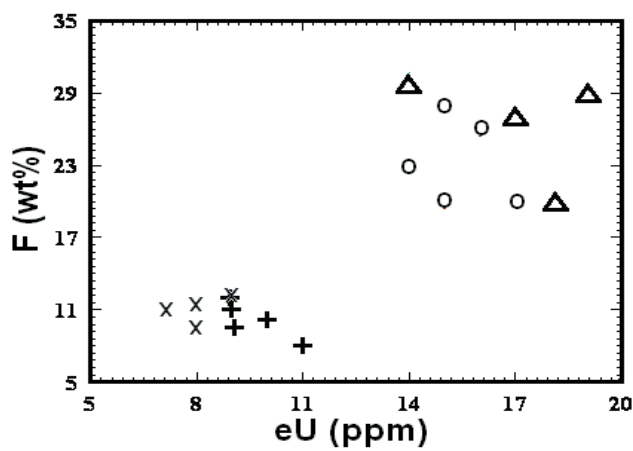

Fig. 24 : eU-F- variation diagram,Symbols as in Fig. 14

On the eU-Pb variation diagram (Fig.25), the studied younger granites do not show any definite relationship. This indicates that the epigenetic processes played the chief role in uranium enrichment, favoring epigenetic uranium addition to these granites.

The variation diagram between eTh and $\mathrm{Nb}$ (Fig.26) shows strong positive correlation indicating the magma forming these granites were emplaced at shallow depths (Briqueu et al., 1984).

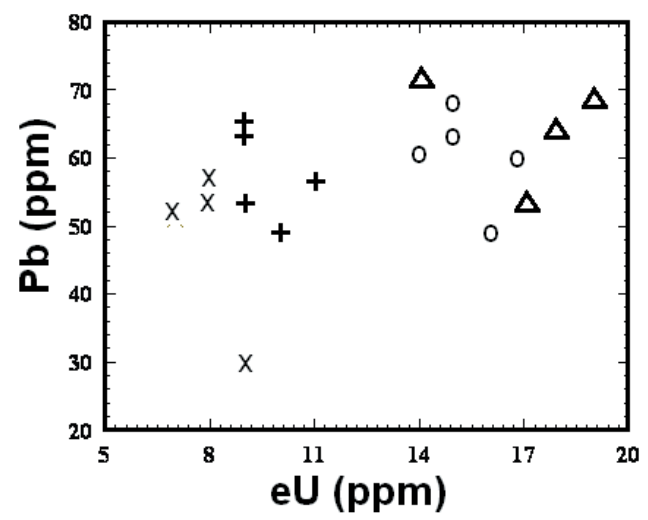

Fig.25: eU-Pb variation diagram,Symbols as in Fig.14 


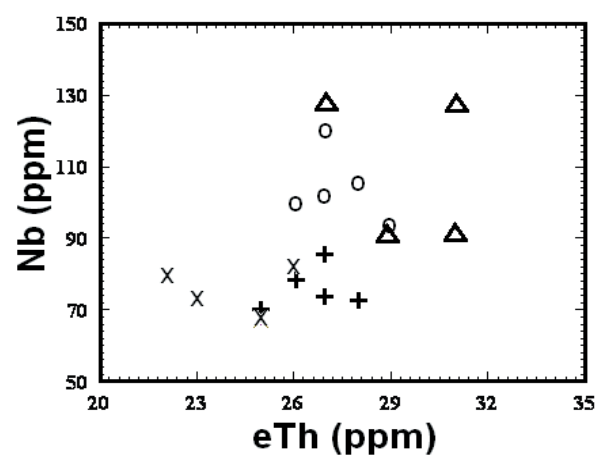

Fig.26: eTh- $\mathrm{Nb}$ variation diagram,Symbols as in Fig.14

\section{Radioactive Anomalies}

Pegmatites in the study area are strongly related to the younger granites, but some of them are recorded invading the older granitoids, especially on the peripheral zones of the studied granitic masses. The pegmatites are abundantly encountered at the southern and western parts of granitic mass of W. Faliq El- Waar rather than granitic mass of W. Faliq El- Sahl. The pegmatites are marking the close of the magmatic differentiation of the most radioactive rocks in the studied area. The anomalous pegmatites are essentially formed of coarse-grained milky quartz, reddish buff orthoclase, flaky biotite and some muscovite with iron oxides. Generally they are located at the marginal parts of the granitic pluton (Fig. 1).

Radiometrically, there are two types of pegmatites, normal pegmatites and anomalous pegmatites. The anomalous pegmatites display highest radioactive values (>444 Ur) due to their mineral composition, as a result of alteration processes associated with radioactive minerals. As stated by Heinrich (1958), these parts developed from volatile-rich magma fluid and/or hydrothermal solutions which evolved from late differentiated magmatic fluids.

The normal pegmatites show gamma radioactivity ranging from $27 \mathrm{Ur}$ to $38 \mathrm{Ur}$. In the anomalous pegmatites, the distribution of gamma radioactivity ranges from 78 to $133 \mathrm{Ur}$, sometimes reaching up to $444 \mathrm{Ur}$ and mainly associated with smoky quartz at its contact with the potash feldspars. Radiometricaly, they have $1200 \mathrm{ppm}$ eU, $340 \mathrm{ppm}$ eTh and $\mathrm{eTh} / \mathrm{eU}$ ratio is 0.3

The major detected radioactive anomalies localized in the W. Faliq El-Sahl and W. Faliq El-Waar area are confined to pegmatite bodies exposed in the area. Petrographic and mineralogic investigations for several mineralized pegmatite samples show high contents of deep violet fluorite and metamict zircon as well as higher contents of iron oxides than those of fresh younger granites. Iron oxides are usually coated or corroded by a thin film of yellowish secondary uranium minerals. Pure hand-picked grains of the uranium minerals were separated from the mineralized pegmatites. The X- ray diffraction (Table 4) and scanning electron microscope patterns show the presence of uranophane as the principal secondary uranium mineral (Fig.27).

Table 4: X-ray diffraction pattern of hand picked uranophane mineral samples

\begin{tabular}{lllrrr}
\hline \multicolumn{2}{c}{ Sp. No. P-1 } & \multicolumn{2}{c}{ Sp. No. P-2 } & \multicolumn{2}{c}{ Uranophane* } \\
\hline dA $^{\mathrm{o}}$ & $\mathrm{I} / \mathrm{I}_{\mathrm{O}}$ & \multicolumn{1}{c}{$\mathrm{dA}^{\mathrm{o}}$} & \multicolumn{1}{c}{$\mathrm{I} / \mathrm{I}_{\mathrm{O}}$} & \multicolumn{1}{c}{$\mathrm{dA}^{\mathrm{o}}$} & $\mathrm{I} / \mathrm{I}_{\mathrm{O}}$ \\
\hline 7.90 & 100 & 7.85 & 100 & 7.88 & 100 \\
6.58 & 35 & 6.60 & 40 & 6.61 & 40 \\
5.40 & 30 & 5.36 & 35 & 5.42 & 40 \\
4.77 & 45 & 4.69 & 40 & 4.76 & 50 \\
3.90 & 90 & 3.99 & 85 & 3.94 & 90 \\
3.51 & 45 & 3.57 & 50 & 3.51 & 40 \\
2.91 & 70 & 2.93 & 75 & 2.99 & 80 \\
2.7 & 40 & 2.68 & 40 & 2.69 & 40 \\
1.89 & 80 & 1.92 & 75 & 1.97 & 70 \\
\hline$*$ ASTM card No.8-*ASTM card NO.8 &
\end{tabular}



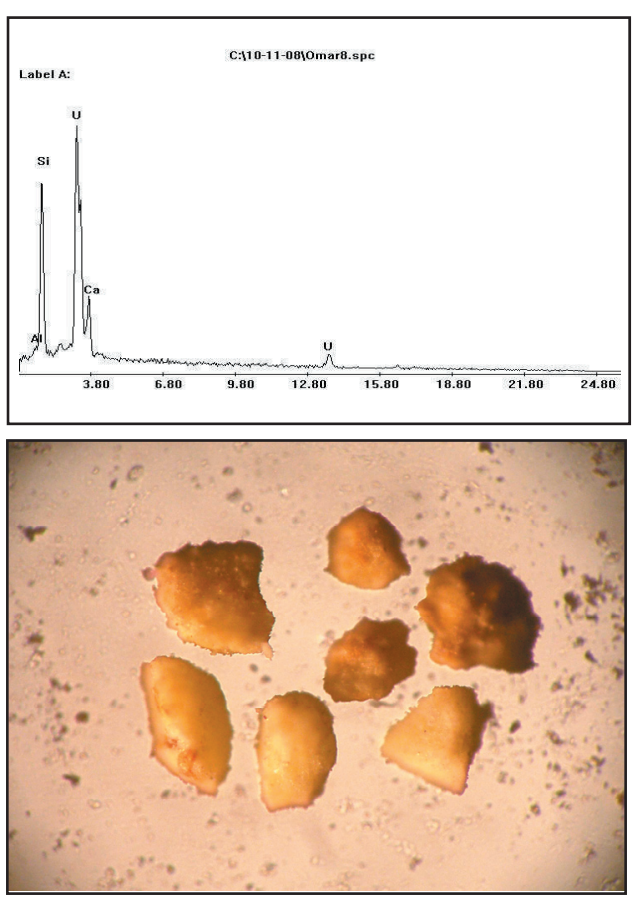

Fig.27: ESEM spectrograph and image of uranophane

\section{CONCLUSION}

The younger granites recorded in the area of W. Faliq El-Sahl and W. Faliq El-Waar, are related to successive magmatic intrusions forming two granitic masses. The main rock types of each of the two masses are monzogranites and syenogranites. The syenogranites are characterized by high radioactive levels compared to the first variety.

The post granitic dykes are mainly represented by dyke swarms ranging in composition from acidic, intermediate to basic. The differential weathering between these dykes and their enclosing country rocks play an important role in the formation of the ridges. The dykes of acidic composition are more resistant to erosion than their enclosing rocks and hence they form ribbon-like elongated ridges exhibiting back-bone feature. While others especially those of basic composition are intensely eroded and form deep elongated trenches in their host rocks.
Geochemically, the studied granites are originated from peraluminous subalkaline magma and are considered as post orogenic within plate granites, intruded in a crust of thickness between $22 \mathrm{~km}$ and $30 \mathrm{~km}$; with $\mathrm{Rb} / \mathrm{Sr}$ ratios range from 0.1 to 1.0 during crystallization of monzogranites but $\mathrm{Rb} / \mathrm{Sr}$ ratios range from 1.0 to 10.0 during crystallization of syenogranites. The geochemical ratios of the studied younger granites show similarity to a great extent suggesting that these granites represent outcrops of one batholith and originated by magmatic differentiation of the same magma.

The syenogranites could be considered as uraniferous granites, originated from highly fractionated, U-rich magma. Their uranium content ranges from 14 to $19 \mathrm{ppm}$, their eTh /eU ratios are very low (1.63-1.93) with $\mathrm{Zr} / \mathrm{Sr}$ ratios are more than 2 . They are highly differentiated, peraluminous, two feldspars and two mica granites.

Both uranium and thorium are essentially concentrated during the magmatic stage in accessory minerals as apatite and zircon. The secondary processes as fracturing and alteration processes allowed the meteoric water and hydrothermal solutions to liberate labile uranium and redeposited their loads along microfractures. This idea is supported by increasing uranium content in the accessory and secondary minerals from monzogranites to syenogranites. Accordingly, in syenogranites uranium was mainly trapped in both accessory (zircon and apatite) and secondary (hematite and fluorite) minerals, but in monzogranites uranium is only restricted to accessory minerals (zircon, sphene and apatite).

Pegmatites show higher U-contents relative to both types of the studied younger granites. Pegmatites could be classified into two separate groups: 1) Mineralized pegmatites located within the syenogranites. They possess secondary uranium mineralization (uranophane) and 2) Non-mineralized pegmatites which are distributed within the monzogranites and show lower U-contents relative to the first type 


\section{REFERENCES}

Abd El Monem, A. A.; Bakhit, F. S., and Ali, M. M.,1990. Trace and rare earth elements geochemistry of El-Erediya, central Eastern Desert, Egypt. Mineralogist, 2, 143-130.

Assaf, H. S.; Mahdy, M. A., and El Afandy, A. H.,1997. Egyptian younger granites, an approach to define parameters favouring formation of uranium deposits. 3rd Conf. Geochem., Alexandria Univ., Egypt, 409 - 420.

Briqueu, L.; Bougault, H., and Joron, J. L.,1984. Quantification of $\mathrm{Nb}, \mathrm{Ta}$, Ti and $\mathrm{V}$ anomalies in magmas associated with subduction zones. Petrogenetic implications, Earth planet. Sci. Lett., 68, 297 - 308.

Cambon, A. R.,1994. Uranium deposits in granitic rocks. Notes on the national training course on uranium geology and exploration. Organized by IAEA and NMA.

Condie, K. C.,1973. Archean magmatism and crustal thickening . Geol. Soc. Amer. Bull., 84, 2981-2991.

Condi, D.C., and Hunter, D.R.,1976. Trace elements geochemistry of Archean granitic rocks from the Barberton region South Africa. Earth Plant, Sci. Lett, 29, 389-400.

Cox, K. G.; Bell, J. D., and Pankhurst, R. J.,1979. The interpretation of igneous rocks. William Clowes, London, Britain, 414 p.

Cuney, M.,1984. Les methods des prospection de l'uranium , Nuclear Energy Agency of the OECD, Paris, 277-292.

Darnley, A.G.,1982. "Hot granites" Some general remarks, In:Uranium in granites (Maurice, Y. J., ed.). Geol. Surv. Canada, paper No. 81-23 ,1-10.

Dostal, J., and Chatterjee, A. K.,2000. Contrasting behaviour of $\mathrm{Nb} / \mathrm{Ta}$ and $\mathrm{Zr} / \mathrm{Hf}$ ratios in a peraluminous granitic pluton, Nova Scotia, Canada. Chem. Geo.,163,207-218.
Hall, A., and Walsh, J. N.,1969. Rapid method for the determination of fluorine in silicate rocks and minerals. Anal. Chem. Acta, 45, 341-342.

Hanson G.N.,1978. The application of trace elements to the petrogenesis of igneous rocks of granitic composition. Earth plant. Sci. Lett. 39, 26-34.

Heier, K. S.,1973. Geochemistry of granulite facies rocks and problems of their origin, Philos. Trans. Roy. Soc., London, Series, 273,429 -442 .

Heinrich, F.W.,1958. Mineralogy of radioactive raw materials. McGraw Hill Book Co., New York, $654 \mathrm{p}$.

Irvine, I.N., and Baragar, W.R.A.,1971. A guide to the chemical classification of the common volcanic rocks. Canadian Earth Sci., 8, 523-548.

London, D.,1992.Phosphorous in S-type magmas: the P2O5 content of feldspars from peraluminous granites, pegmatites and rhyolites. Am. Mineral. 77,126-145.

Maniar, P. D., and Piccoli, P. M.,1989. Tectonic discrimination of granitoids. Geol. Soc. Am. Bull., No.101, 635-643.

Mason, B.,1966. Principles of geochemistry 3rd Ed. John Wiley, New York, 310 p.

Moharem, A. F.,1999. Geology and geochemistry and radioactivity of the area of Gabal ElMaghrabiya, central Eastern Desert, Egypt. Ph. D. Thesis, Fac. Sci., Ain Shams Univ., Cairo, Egypt, $211 \mathrm{p}$.

O'Connor, J.T.,1965. A classification for quartzrich igneous rocks based on feldspar ratio. U.S. Geol. Surv. Prof. Paper., 525-B,79-84.

Pagel, M.,1982. The mineralogy and geochemistry of uranium, thorium and rare earth elements in the two radioactive granites of the Vosages, France. Mineral. magazine, 46, 149-161.

Pearce, J.A.; Harris, N.B.W., and Tindle, A.G.,1984. Trace element discrimination diagrams for the tectonic interpretation of granitic rocks. J. Petrol., 25, 958-983. 
Pier, C. A.,1992. Geochemistry of granites and trachytes from the Summit region of Mt. Kenya. Contrib. Mineral. Petrol., 89, 394-409.

Raguin, E.,1965. Geology of granites. Interscience Pub.J. Wiley, London, 314 p.

Rogers, J. J. W., and Adams, J. S. S.,1969. Uranium. In : Handbook of geochemistry (Wedepohl , K. H., ed.). New York, Springer - Verlag, 4, 92 B1- 92 C10.

Rogers, J. J. W.; Ghuma, M. A.; Nagy, R. M.; Greenberg, J. K., and Fullagar, P. D.,1978. Plutonism in Pan-African belts and the geologic evolution of north eastern Africa. Earth Planet Sci. Lett., 39, $109-117$.

Salman, A.B.; El Kholy, D.M., and El Zalaky, M.A.,2005, Relation between granite plutonism, faulting and uranium mineralization in the northern part of Gabal Qattar area, Northern Eastern Desert, Egypt. Al Azhar Bull. Sci.,16 (1), 23-35.

Samaan, J.M.,2000. Geology, Petrology and Radioactivity of the Basement Rocks of Gebel Uqap El Nugum-Gebel Seiga area, South Wadi Garara, South Eastern Desert, Egypt. Ph.D.Thesis, Cairo Univ.,Egypt, 247p.

Scheepers, R.,2000. Granites of the Saldania Mobile Belt, South Africa: radioelements and $\mathrm{P}$ as discriminators applied to metallogeny. J. Geochem. Exp., 68, 69-86.
Scheepers, R., and Rozendaal, A.,1995. Phosphorus as typological and mineralization potential indicator; the Cap granite suite of the Saldania Mobile belt as a case study. J. Afr. Sci., 21(1) , 127-140.

Shalaby, M.H.; Ammar, F.A.; Darwish, M.E., and E1 Sawey, E. H.,2009. Mineralogy and radiometry of the episyenitizaed granitic rocks of Gabal Qattar area, North Eastern Desert, Egypt. Sci. J. Fac. Sci, Minufia Univ., XXIII, 161-188.

Shalaby, M.H., and Moharem, A. F.,2008. Geochemical Behaviour of Radio-Elements in Some Younger Granites of Central Eastern Desert, Egypt. Al-Azhar Univ., Egypt. 6th AlAzhar Inter. Sci. Conf. (AISC'08).

Shand, S.J.,1951. Eruptive rocks. John Wiley, New York.

Shapiro, L., and Brannock, W. W.,1962, Rapid analysis of silicate, carbonate and phosphate rocks. U.S. Geol. Surv. Bull. 1144A, 56 p.

Steenfelt, A.,1982. Uranium and selected trace elements in granites from the Calidonides of East Greenland. Min. Mag., 46,201 - 210.

Streckeisen, A.,1976. To each plutonic rock its proper name. Earth Sci. Rev., 12,1-33. 


\section{جيولوجية وبترولوجية وتوزيع اليورانيوم فى الكتل الجرانيتية الحديثة

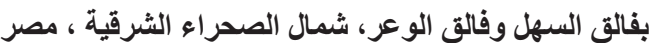

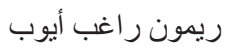

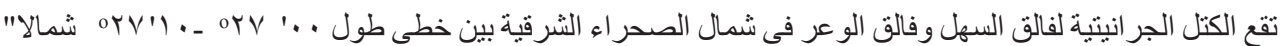

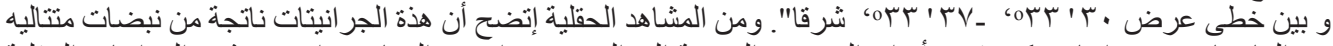

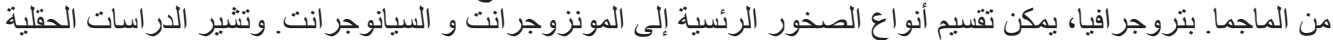

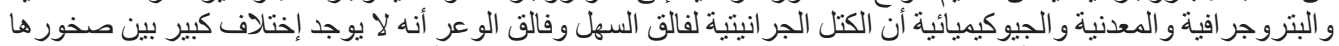

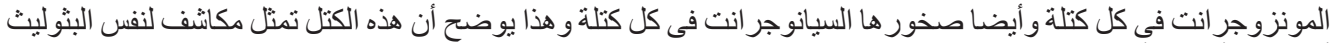

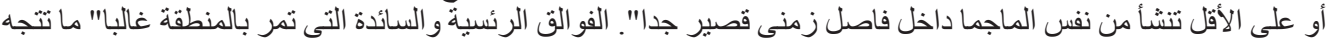

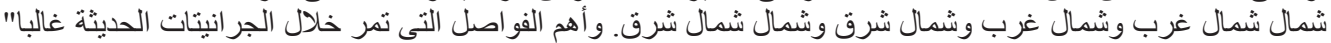

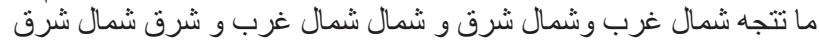

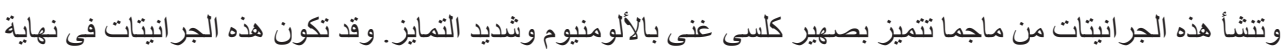

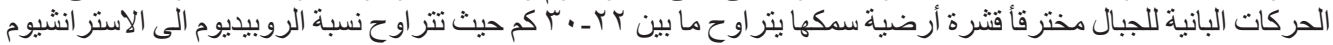

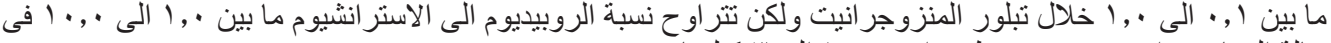

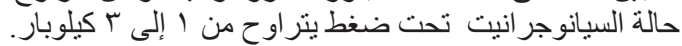

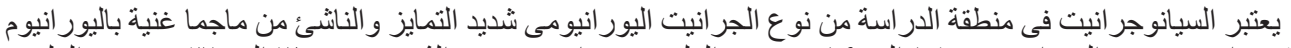

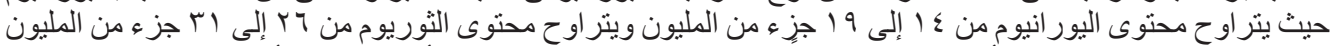

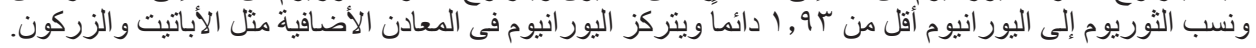

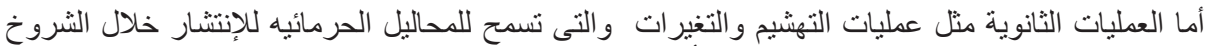

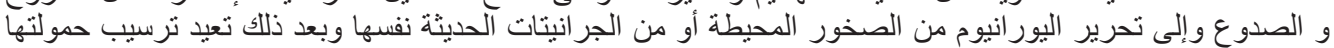

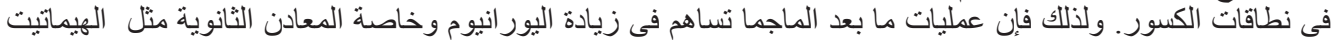
و الفلور ايت و المعادن الطينية و أكاسيد الحديد.

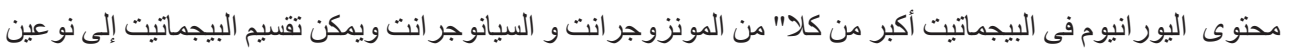

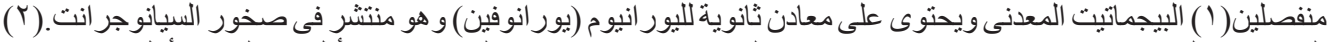

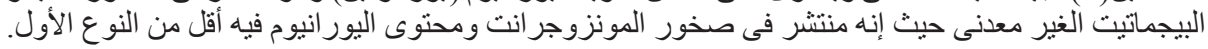

